\title{
Classification of Extraction Sockets Based Upon Soft and Hard Tissue Components
}

\author{
Gintaras Juodzbalys, * Dalius Sakavicius, * and Hom-Lay Wang ${ }^{\dagger}$
}

Background: The aim of this study was to present and validate a new classification system for the maxillary anterior extraction socket based upon soft and hard tissue parameters.

Methods: Twenty-five maxillary anterior teeth from 25 subjects ( 15 men and 10 women; aged 18 to 51 years; mean age $=$ 32.4 years) were used to validate the new proposed classification system. Two independent surgeons recommended a treatment approach based upon the classification proposed. These suggestions were verified at the time of surgery. Weighted Cohen's $\kappa$ was used to calculate interobserver reliability. Statistical analysis was performed using the paired $t$, KolmagorovSmirnov, and marginal homogeneity tests.

Results: Interobserver agreement and weighted Cohen's $\kappa$ were $96 \%$ and 0.94 , respectively. This indicated a high reliability for the proposed classification system. No peri-implant soft tissues were classified as deficient when the newly developed classification was used to recommend treatment. Overall, $80 \%$ of sockets were graded as adequate based on soft tissue parameters $(P<0.001)$.

Conclusion: The extraction socket classification proposed here is an objective and helpful tool for socket assessment and for promoting future implant esthetics. J Periodontol 2008; 79:413-424.

\section{KEY WORDS}

Bone regeneration; dental implants; esthetics; osseointegration.

\footnotetext{
* Department of Oral and Maxillofacial Surgery, Kaunas University of Medicine, Kaunas, Lithuania.

$\dagger$ Department of Periodontics and Oral Medicine, University of Michigan, Ann Arbor MI.
}

$\mathrm{T}$ The immediate replacement of teeth by implants was proposed $>20$ years ago. ${ }^{1}$ This method of treatment reduces the waiting period between tooth extraction and prosthetic rehabilitation. ${ }^{2-9}$ Because implant survival and success rates are high, the implant's esthetic outcome has become the main focus of interest. ${ }^{10-12}$ Therefore, it is generally agreed that implant success criteria should include an esthetic component. ${ }^{13}$

The level of bone support and the soft tissue dimensions around the implantsupported single-tooth restoration are key factors in the final esthetic outcome. ${ }^{14}$ Araujo et al. ${ }^{15-18}$ showed that placement of an implant in a fresh extraction site failed to prevent the remodeling that occurred in the walls of the socket. It was suggested that the resorption of the socket walls that occurs following tooth removal must be considered to ensure proper implant placement. ${ }^{19}$ Labial plate position, its thickness, and bone loss are important considerations for esthetic implantation and, in many cases, may necessitate hard tissue augmentation. ${ }^{20,21}$ The condition of the peri-implant soft tissue, e.g., tissue level, color, and texture, are other critical determinants for final implant esthetics. ${ }^{22-24}$ Furthermore, the presence of periodontal infection might jeopardize the outcome of immediate implant placement ${ }^{7,25,26}$ because

doi: 10.1902/jop.2008.070397 
Table I.

Data for Subjects, Defect Sites, and Implants

\begin{tabular}{|c|c|c|c|c|c|}
\hline Subject \# & Gender & Age (years) & Tooth \# & Reason for Tooth Extraction & Implant Length/Diameter (mm) \\
\hline 1 & Female & 18 & 8 & Periapical infection & $12 / 4.1$ \\
\hline 2 & Male & 30 & 8 & Root fracture & $16 / 4.1$ \\
\hline 3 & Male & 18 & 9 & Root fracture & $|4 / 4|$. \\
\hline 4 & Female & 42 & 7 & Periapical infection & $12 / 3.3$ \\
\hline 5 & Male & 31 & 8 & Root fracture & $16 / 4.1$ \\
\hline 6 & Male & 42 & 9 & Periapical perforation & $16 / 4.1$ \\
\hline 7 & Female & 49 & 6 & Root fracture & $12 / 4.1$ \\
\hline 8 & Male & 28 & 8 & Root fracture & $16 / 4.1$ \\
\hline 9 & Male & 51 & 7 & Caries & $|4 / 4|$. \\
\hline 10 & Male & 22 & 10 & Periapical infection & $16 / 4.1$ \\
\hline 11 & Female & 26 & 9 & Periapical perforation & |4/4.| \\
\hline 12 & Male & 19 & 10 & Root fracture & $16 / 4.1$ \\
\hline 13 & Male & 24 & 7 & Caries & $16 / 4.1$ \\
\hline 14 & Female & 27 & 9 & Caries & $|4 / 4|$. \\
\hline 15 & Female & 36 & 11 & Periapical perforation & $14 / 3.3$ \\
\hline 16 & Male & 28 & 11 & Root fracture & $16 / 4.1$ \\
\hline 17 & Male & 42 & 9 & Caries & $|4 / 4|$. \\
\hline 18 & Female & 40 & 6 & Root fracture & $16 / 4.1$ \\
\hline 19 & Male & 31 & 7 & Periapical perforation & $16 / 4 . \mid$ \\
\hline 20 & Male & 28 & 8 & Periapical infection & $16 / 4.1$ \\
\hline 21 & Female & 37 & 6 & Periapical infection & $14 / 3.3$ \\
\hline 22 & Female & 42 & 11 & Caries & $14 / 3.3$ \\
\hline 23 & Male & 34 & 10 & Root fracture & $16 / 3.3$ \\
\hline 24 & Female & 31 & 10 & Root fracture & $14 / 3.3$ \\
\hline 25 & Male & 35 & 7 & Root fracture & $|4 / 4|$. \\
\hline
\end{tabular}

it interferes with flap manipulation and it is difficult to eradicate infection from the hard tissues. ${ }^{26,27}$

Hence, the accurate evaluation of the extraction socket is crucial and only can be made immediately following tooth extraction. ${ }^{28}$ One classification of extraction defects proposed by Caplanis et al. ${ }^{28}$ showed some promising features. However, this classification is too general and failed to distinguish concrete assessments that are essential for extraction socket classification, especially in the esthetic zone. Therefore, the aim of this study was to develop and validate a new classification for extraction sockets immediately following tooth removal. This classification system is based upon soft and hard tissue conditions. Also included in this classification system is the proposed treatment recommendation.

\section{MATERIALS AND METHODS}

\section{Subject Sample}

Twenty-five subjects, 15 men and 10 women (age: 18 to 51 years; mean \pm SD: $32.4 \pm 9.1$ years), who needed dental implants at the Department of Maxillofacial Surgery, University of Kaunas, were enrolled consecutively in the investigation. All participants read and 
Table 2.

\section{Extraction Socket Soft and Hard Tissue Assessments and Extraction Socket Types}

\begin{tabular}{|c|c|c|c|}
\hline \multirow[b]{2}{*}{ Assessment } & \multicolumn{3}{|c|}{ Extraction Socket Types } \\
\hline & Adequate & Compromised & Deficient \\
\hline \multicolumn{4}{|l|}{ Soft tissue } \\
\hline \multicolumn{4}{|l|}{ Quantity } \\
\hline Soft tissue contour variations & No & $<2 \mathrm{~mm}$ & $\geq 2 \mathrm{~mm}$ \\
\hline Soft tissue vertical deficiency & No & I to $2 \mathrm{~mm}$ & $>2 \mathrm{~mm}$ \\
\hline KG width $(\mathrm{mm})$ & $>2$ & 1 to 2 & $<1$ \\
\hline $\begin{array}{l}\text { Mesial and distal papillae appearance } \\
\text { (Nordland and Tarnow }{ }^{34} \text { ) }\end{array}$ & । & $\|$ & III \\
\hline \multicolumn{4}{|l|}{ Quality } \\
\hline $\begin{array}{l}\text { Soft tissue color, consistency, and } \\
\text { contour }\end{array}$ & $\begin{array}{l}\text { Pink, firm, and } \\
\text { smooth }\end{array}$ & $\begin{array}{l}\text { Slightly red and a soft, } \\
\text { spongy, and uneven } \\
\text { contour }\end{array}$ & $\begin{array}{l}\text { Red/bluish or red with a soft } \\
\text { edematous and boggy or } \\
\text { craterlike appearance }\end{array}$ \\
\hline \multicolumn{4}{|l|}{ Biotype } \\
\hline Biotype of gingival tissue (mm) & Thick $(\geq 2.0)$ & Moderate $(\geq 1.0$ to $<2.0)$ & Thin $(<1.0)$ \\
\hline \multicolumn{4}{|l|}{ Hard tissue } \\
\hline Height of alveolar process (mm) & $>10$ & $>8$ to $\leq 10$ & $\leq 8$ \\
\hline $\begin{array}{l}\text { Available bone beyond the apex of } \\
\text { extraction socket }(\mathrm{mm})\end{array}$ & $\geq 4$ & $\geq 3$ to $<4$ & $<3$ \\
\hline $\begin{array}{l}\text { Extraction socket labial plate vertical } \\
\text { position }(\mathrm{mm})\end{array}$ & $\leq 3$ & $>3$ to $<7$ & $\geq 7$ \\
\hline Extraction socket facial bone thickness (mm) & $\geq 2$ & $\geq 1$ to $<2$ & $<1$ \\
\hline Presence of socket bone lesions & No & Yes & Yes \\
\hline $\begin{array}{l}\text { Mesial and distal intradental bone peak } \\
\text { height }(\mathrm{mm})\end{array}$ & 3 to 4 & $\geq 1$ to $<3$ & $<1$ \\
\hline $\begin{array}{l}\text { Mesio-distal distance between adjacent } \\
\text { teeth }(\mathrm{mm})\end{array}$ & $\geq 7$ & $>5$ to $<7$ & $\leq 5$ \\
\hline Need for palatal angulation & $<5^{\circ}$ & $5^{\circ}$ to $30^{\circ}$ & $>30^{\circ}$ \\
\hline
\end{tabular}

signed an informed consent form. The use of human subjects in this study was reviewed and approved by the Health Science Institutional Review Board of the University of Kaunas. Subjects with severe systemic health problems, e.g., uncontrolled diabetes, immunodeficiency diseases, and heavy smokers (more than 10 cigarettes a day), were excluded from the study.

Twenty-five teeth in the frontal maxilla were extracted: 10 central incisors, nine lateral incisors, and six canines. Causes for extraction were root fracture, perforation, peri-apical infection, and untreatable caries. Twenty-five screw-shaped dental implants ${ }^{\ddagger}$ were placed accordingly (Table 1 ). This study was conducted from April 1, 2004 to December 1, 2006.

\section{Tooth Extraction}

After local anesthesia, $\$$ teeth were extracted gently, and extreme care was taken to avoid fracture of the socket walls. To achieve this aim, an intrasulcular incision using a $15 \mathrm{c}$ blade was made carefully around the extracted maxillary tooth. A palatal approach was used for atraumatic tooth extraction. Sites were degranulated carefully to ensure proper visualization and assessment.

\section{Socket Classification and Assessments}

Below is an overview of the proposed extraction socket classification (Table 2 and Fig. 1). This classification is derived from soft and hard tissue variables. 1) Soft tissue contour variations: vertical distance between the socket and adjacent teeth's buccal gingival scallop margin. The soft tissue contour closely mimics that of adjacent natural teeth and is critical in achieving a final esthetic restoration. ${ }^{14,21}$ No gap, $<2$, and $\geq 2$ $\mathrm{mm}$ were defined as adequate, compromised, and deficient, respectively. 2) Vertical soft tissue deficiency: vertical distance between the socket and adjacent teeth's buccal mucosa tissues margin; 0,1 to 2 , and $>2 \mathrm{~mm}$ were used to define vertical height as adequate, compromised, and deficient, respectively. A

\# Straumann Standard Plus, Straumann, Basel, Switzerland. $\S$ Ubistesini, 3M ESPE Dental, Seefeld, Germany. 


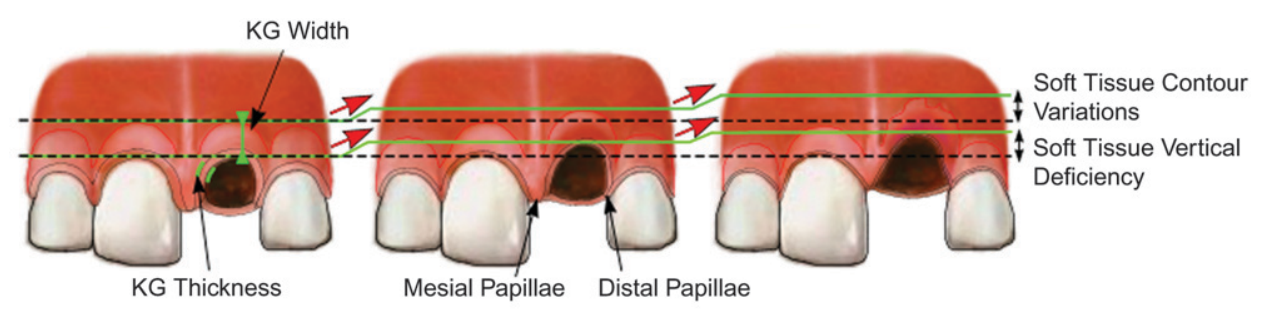

Soft Tissue Assessment

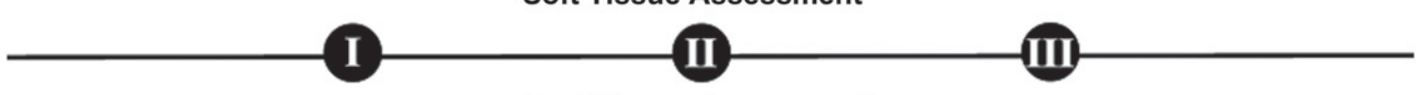

Hard Tissue Assessment

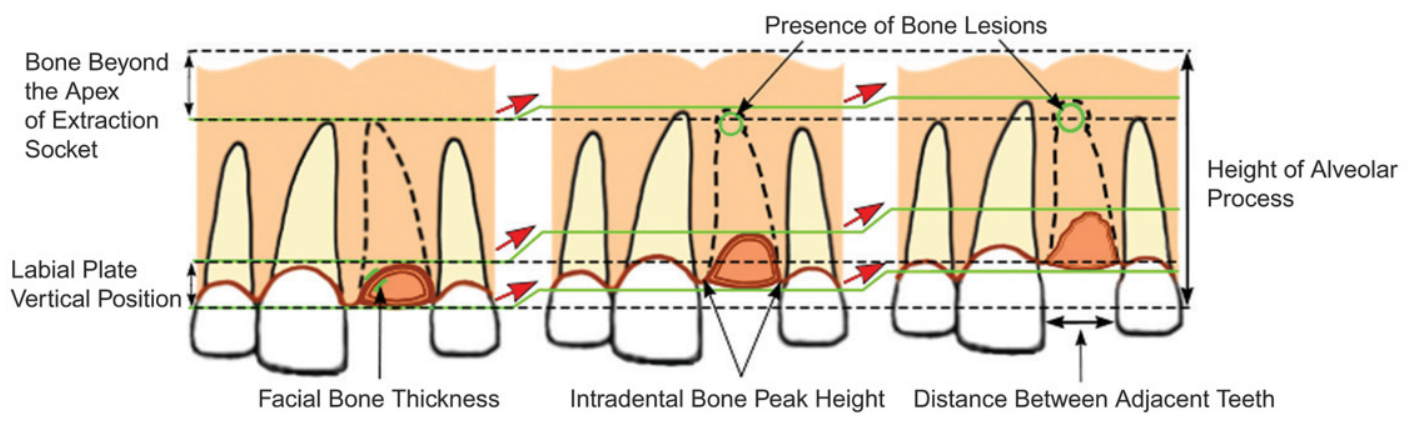

Figure I.

Extraction socket soft and hard tissue assessments and extraction socket types. I, II, and III = assessment scores.

compromised esthetic result is expected when a 1 - to 2 -mm vertical deficiency is noted. ${ }^{9}$ For defects $\geq 2$ $\mathrm{mm}$, soft tissue augmentation should be considered prior to implant insertion. ${ }^{21}$ 3) The keratinized gingival (KG) width on the mid-buccal side of the socket: $\geq 2$, 1 to 2 , and $<1 \mathrm{~mm}$ were defined as adequate, compromised, and deficient, respectively. The existing KG helps tight tissue adaptation and provides a connective tissue circumferential fiber system that resists mechanical stress. ${ }^{29-33}$ A mean KG width $\geq 2 \mathrm{~mm}$ was considered to be optimal for an esthetic restoration. ${ }^{9}$ 4) Mesial and distal papillae appearance using the classification described by Nordland and Tarnow. ${ }^{34}$ 5) Gingival tissue biotype was characterized by fibrotic gingival thickness as thick $(\geq 2.0 \mathrm{~mm})$, moderate $(\geq 1.0$ to $<2.0 \mathrm{~mm})$, or thin $\left.(<1.0 \mathrm{~mm}) .{ }^{35} 6\right)$ Soft tissue quality: pink and firm with a normal contour was classified as adequate; a slightly red color and a soft, spongy, and uneven contour was classified as compromised; and red gingiva with a soft edematous and boggy or craterlike appearance was classified as deficient. 7) The height of the alveolar process: the distance between the tip of the extraction socket labial plate and the nasal sinus floor. To facilitate a better implant/crown ratio, the minimal dental implant length in the anterior maxillary region is $10 \mathrm{~mm} .{ }^{36}$ Hence, the alveolar process height should be $\geq 10 \mathrm{~mm}$ because the recommended apico-coronal position of the dental implant is 2 to $3 \mathrm{~mm}$ below the adjacent cemento- enamel junction (CEJ). ${ }^{13,37} \mathrm{~A}$ height for the alveolar process of $>8$ to $\leq 10 \mathrm{~mm}$ was defined as compromised, and $\leq 8 \mathrm{~mm}$ was defined as deficient. 8) Available bone beyond the apex of extraction socket: the distance between the socket apex and the nasal sinus floor. To achieve implant primary stability, available bone beyond the extraction socket margin should be $\geq 4 \mathrm{~mm}$ (or $\geq 3 \mathrm{~mm}$ in a case of compromised bone height). ${ }^{7,8}$ The height of the alveolar process and the available remaining bone were estimated from the orthopantomogram," taking into consideration the average $x$-ray magnification of $20 \%$. The evaluation of the radiographs was performed in a linear fashion using a standardized computerized system whereby the measurements were obtained by drawing a line between the tip of the extraction socket labial plate and the nasal sinus floor (the height of the alveolar process) and between the socket apex and the nasal sinus floor (available bone beyond the apex of the extraction socket). 9) Extraction socket labial plate vertical position: the distance between the tip of the extraction socket labial plate and the CEJ of the adjacent teeth. Adequate distance was estimated to be $\leq 3 \mathrm{~mm} .{ }^{21}$ If compromised ( $>3$ to $<7 \mathrm{~mm}$ ), a guided bone regeneration (GBR) procedure often is required. When the distance is $\geq 7 \mathrm{~mm}$, immediate implant placement is contraindicated because the risk

|| Cranex-3, Soredex, Finland. 
Table 3.

Extraction Socket Soft Tissue Assessments by Surgeons 1 and 2

\begin{tabular}{|c|c|c|c|c|c|c|c|c|c|c|c|c|c|c|c|c|c|}
\hline \multirow{2}{*}{\multicolumn{2}{|c|}{ Subject \# Tooth \# }} & \multicolumn{2}{|c|}{$\begin{array}{l}\text { Soft Tissue } \\
\text { Contour } \\
\text { Variations } \\
(\mathrm{mm})\end{array}$} & \multicolumn{2}{|c|}{$\begin{array}{l}\text { Soft Tissue } \\
\text { Vertical } \\
\text { Deficiency } \\
\text { (mm) }\end{array}$} & \multicolumn{2}{|c|}{$\begin{array}{l}\text { KG } \\
\text { Width } \\
(\mathrm{mm})\end{array}$} & \multicolumn{2}{|c|}{$\begin{array}{c}\text { Mesial } \\
\text { Papillae } \\
\text { Appearance } \\
\text { (class) }\end{array}$} & \multicolumn{2}{|c|}{$\begin{array}{c}\text { Distal } \\
\text { Papillae } \\
\text { Appearance } \\
\text { (class) }\end{array}$} & \multicolumn{2}{|c|}{$\begin{array}{c}\text { Soft Tissue } \\
\text { Quality }\end{array}$} & \multicolumn{2}{|c|}{$\begin{array}{l}\text { Gingival } \\
\text { Biotype }\end{array}$} & \multicolumn{2}{|c|}{$\begin{array}{c}\text { ES Type } \\
\text { According to } \\
\text { Soft Tissue } \\
\text { Assessments (I to III) }\end{array}$} \\
\hline & & SI & S2 & SI & S2 & SI & S2 & SI & S2 & SI & S2 & SI & S2 & SI & S2 & SI & S2 \\
\hline । & 8 & 0 & 0 & 0 & 0 & 3 & 3 & I & । & 1 & । & $A$ & A & Thick & Thick & 1 & । \\
\hline 2 & 8 & 2 & 2 & । & । & 2 & 2 & $\|$ & $\|$ & 1 & 1 & C & C & \multicolumn{2}{|c|}{ Moderate Moderate } & $\|$ & $\|$ \\
\hline 3 & 9 & 0 & 0 & 0 & 0 & 5 & 4 & 1 & 1 & 1 & 1 & A & A & Thick & Thick & 1 & 1 \\
\hline 4 & 7 & । & । & 2 & 2 & 3 & 3 & $\|$ & $\|$ & 1 & I & C & C & Thick & Thick & $\|$ & $\|$ \\
\hline 5 & 8 & 0 & 0 & 0 & 0 & 3 & 3 & । & । & 1 & 1 & C & $C$ & \multicolumn{2}{|c|}{ Moderate Moderate } & $\|$ & $\|$ \\
\hline 6 & 9 & 0 & 0 & 0 & 0 & 5 & 5 & 1 & । & 1 & I & A & A & Thick & Thick & 1 & । \\
\hline 7 & 6 & 3 & 2 & 2 & 2 & 3 & 3 & III & III & III & III & $\mathrm{D}$ & C & Thick & Thick & III & III \\
\hline 8 & 8 & 0 & 0 & 0 & 0 & 4 & 4 & I & 1 & 1 & I & A & A & Thick & Thick & 1 & 1 \\
\hline 9 & 7 & 1 & 0 & 2 & 2 & 5 & 5 & $\|$ & $\|$ & $\|$ & $\|$ & C & C & Thin & Thin & III & III \\
\hline 10 & 10 & 0 & 0 & 0 & 0 & 2 & 2 & I & 1 & 1 & 1 & $A$ & $A$ & Thin & Thin & III & III \\
\hline 11 & 9 & 1 & 1 & 0 & 0 & 2 & 2 & $\|$ & $\|$ & 1 & 1 & C & C & Thick & Thick & $\|$ & $\|$ \\
\hline 12 & 10 & 3 & 3 & 1 & 1 & 3 & 3 & $\|$ & $\|$ & $\|$ & ॥ & C & $D$ & Thick & Thick & III & III \\
\hline 13 & 7 & 0 & 0 & 0 & 0 & 2 & 2 & I & 1 & 1 & I & C & $C$ & Thick & Thick & $\|$ & $\|$ \\
\hline 14 & 9 & 1 & 0 & 1 & 1 & 4 & 4 & $\|$ & $\|$ & 1 & I & C & C & \multicolumn{2}{|c|}{ Moderate Moderate } & $\|$ & $\|$ \\
\hline 15 & 11 & 0 & 0 & 0 & 0 & 2 & 2 & $\|$ & $\|$ & $\|$ & $\|$ & C & C & \multicolumn{2}{|c|}{ Moderate Moderate } & $\|$ & $\|$ \\
\hline 16 & 11 & 3 & 2 & 2 & 2 & 4 & 4 & $\|$ & $\|$ & $\|$ & $\|$ & $\mathrm{D}$ & $\mathrm{D}$ & Thick & Thick & III & III \\
\hline 17 & 9 & 2 & 2 & 2 & 2 & 5 & 5 & III & III & $\|$ & $\|$ & C & C & Thin & Thin & III & III \\
\hline 18 & 6 & 0 & 0 & 0 & 0 & 3 & 3 & । & I & 1 & 1 & C & D & Moderate & Thin & $\|$ & III \\
\hline 19 & 7 & 0 & 0 & 0 & 0 & 5 & 5 & 1 & 1 & 1 & 1 & A & A & Thick & Thick & 1 & । \\
\hline 20 & 8 & 2 & 2 & । & 1 & 4 & 4 & $\|$ & $\|$ & 1 & $\|$ & $\mathrm{D}$ & $\mathrm{D}$ & Moderate & Thin & III & III \\
\hline 21 & 6 & 0 & 0 & 0 & 0 & 3 & 3 & $\|$ & $\|$ & $\|$ & $\|$ & C & $C$ & Moderate & Thin & $\|$ & $\|$ \\
\hline 22 & 11 & 1 & 1 & I & 1 & 5 & 5 & $\|$ & $\|$ & $\|$ & $\|$ & C & C & Thick & Thick & $\|$ & $\|$ \\
\hline 23 & 10 & 0 & 0 & 0 & 0 & 4 & 4 & । & । & 1 & 1 & A & A & Thick & Thick & 1 & 1 \\
\hline 24 & 10 & 0 & 0 & 0 & 0 & 3 & 3 & $\|$ & $\|$ & 1 & 1 & A & A & \multicolumn{2}{|c|}{ Moderate Moderate } & $\|$ & $\|$ \\
\hline 25 & 7 & 0 & 0 & 0 & 0 & 5 & 4 & 1 & I & 1 & I & A & A & Thick & Thick & 1 & । \\
\hline \multicolumn{2}{|c|}{$\begin{array}{l}\text { Observed } \\
\text { agreement (\%) }\end{array}$} & \multicolumn{2}{|c|}{84} & \multicolumn{2}{|c|}{100} & \multicolumn{2}{|c|}{92} & \multicolumn{2}{|c|}{100} & \multicolumn{2}{|c|}{96} & \multicolumn{2}{|c|}{88} & \multicolumn{2}{|c|}{88} & \multicolumn{2}{|c|}{96} \\
\hline Cohen's $\mathrm{k}$ & & \multicolumn{2}{|c|}{0.73} & \multicolumn{2}{|c|}{1.0} & \multicolumn{2}{|c|}{0.80} & & & & & & & 0.8 & & & \\
\hline
\end{tabular}

$\mathrm{ES}=$ extraction socket; $\mathrm{S} 1=$ surgeon $1 ; \mathrm{S} 2=$ surgeon $2 ; \mathrm{A}=$ adequate; $\mathrm{C}=$ compromised; $\mathrm{D}=$ deficient.

for soft tissue recession is proportional to the distance between the existing bone and soft tissue. The more distant the position of the alveolus to the soft tissues, the greater the risk for gingival recession. ${ }^{38} 10$ )
Extraction socket facial bone thickness: measured at the 1-, 2-, 3-, 4-, 5-, and 6-mm levels with ridgemapping calipers. To maintain the implant soft tissue profile and to ensure implant esthetics, a minimal labial 
Table 4.

\section{Extraction Socket Hard Tissue Assessments by Surgeons 1 and 2}

\begin{tabular}{|c|c|c|c|c|c|c|c|c|c|c|c|}
\hline \multirow[b]{2}{*}{ Subject \# } & \multirow[b]{2}{*}{ Tooth \# } & \multicolumn{2}{|c|}{$\begin{array}{c}\text { Height of } \\
\text { Alveolar } \\
\text { Process (mm) }\end{array}$} & \multicolumn{2}{|c|}{$\begin{array}{l}\text { Available Bone } \\
\text { Beyond the } \\
\text { Apex (mm) }\end{array}$} & \multicolumn{2}{|c|}{$\begin{array}{c}\text { ES Facial } \\
\text { Bone Thickness } \\
(\mathrm{mm})\end{array}$} & \multicolumn{2}{|c|}{$\begin{array}{l}\text { Need for } \\
\text { Palatal } \\
\text { Angulation }\left(^{\circ}\right)\end{array}$} & \multicolumn{2}{|c|}{$\begin{array}{c}\text { ES Labial } \\
\text { Plate Vertical } \\
\text { Position }(\mathrm{mm})\end{array}$} \\
\hline & & SI & s2 & SI & S2 & SI & \$2 & SI & S2 & SI & s2 \\
\hline I & 8 & 15 & 15.3 & 4.6 & 5 & 2 & 2.2 & 0 & 0 & 0 & 0 \\
\hline 2 & 8 & 19.8 & 20 & 5.6 & 6 & 1.6 & 1.8 & 4 & 3 & 4 & 4 \\
\hline 3 & 9 & 17.5 & 17.3 & 5.5 & 5.4 & 2.6 & 2.5 & 0 & 0 & I & 0 \\
\hline 4 & 7 & 14.4 & 14.5 & 4.5 & 4.5 & 2.5 & 2.5 & 6 & 7 & 2 & 2 \\
\hline 5 & 8 & 19.2 & 19.2 & 6.2 & 6.2 & 2.6 & 2.7 & 0 & 0 & 1 & 1 \\
\hline 6 & 9 & 18.3 & 18.3 & 4.5 & 4.3 & 2.2 & 2.2 & 0 & 0 & 0 & 0 \\
\hline 7 & 6 & 14 & 14 & 3.6 & 3.6 & 1.1 & 0.9 & 15 & 17 & 4 & 5 \\
\hline 8 & 8 & 20.2 & 20.2 & 6.2 & 6.4 & 2.9 & 2.8 & 0 & 0 & 0 & 0 \\
\hline 9 & 7 & 16.5 & 16.6 & 4.4 & 4.3 & 2.8 & 2.8 & 12 & 14 & 2 & 2 \\
\hline 10 & 10 & 19.6 & 19.6 & 5 & 5.1 & 3 & 3 & 0 & 0 & 0 & 0 \\
\hline 11 & 9 & 17.7 & 17.6 & 5.1 & 5 & 1.6 & 1.6 & 5 & 4 & 2 & 2 \\
\hline 12 & 10 & 20.3 & 20.1 & 6.3 & 6.3 & 2.3 & 2.2 & 0 & 0 & 5 & 4 \\
\hline 13 & 7 & 18.5 & 18.5 & 4.5 & 4.5 & 2.4 & 2.3 & 0 & 0 & 2 & 2 \\
\hline 14 & 9 & 16.9 & 16.9 & 5.1 & 5.1 & 2.4 & 2.4 & 6 & 6 & 2 & 2 \\
\hline 15 & 11 & 17.5 & 17.5 & 4.8 & 4.6 & 2.3 & 2.3 & 12 & 14 & 0 & 0 \\
\hline 16 & II & 20.4 & 20.3 & 6.5 & 6.5 & 2.2 & 2.2 & 0 & 0 & 2 & 2 \\
\hline 17 & 9 & 17.5 & 17.2 & 3.4 & 3.6 & 1.2 & 1 & 30 & 32 & 3 & 3 \\
\hline 18 & 6 & 18 & 18 & 4.4 & 4.2 & 1.1 & 1 & 24 & 24 & 0 & 0 \\
\hline 19 & 7 & 20.3 & 20.3 & 6 & 5.6 & 3 & 3 & 0 & 0 & 0 & 0 \\
\hline 20 & 8 & | 8.4 & 18.4 & 4.6 & 4.6 & 2.1 & 2.1 & 10 & 12 & 0 & 0 \\
\hline 21 & 6 & 17.6 & 17.6 & 2.5 & 2.5 & 1.4 & 1.4 & 24 & 24 & 1 & I \\
\hline 22 & 11 & 16.8 & 16.8 & 4,1 & 4.1 & 1.8 & 1.6 & 19 & 19 & 2 & 2 \\
\hline 23 & 10 & 19.1 & 18.8 & 5.2 & 5.2 & 3 & 3 & 2 & 2 & 0 & 0 \\
\hline 24 & 10 & 17.3 & 17.3 & 5 & 5 & 1.4 & 1.4 & 0 & 0 & 2 & 2 \\
\hline 25 & 7 & 16.7 & 16.5 & 4.3 & 4.3 & 2.3 & 2.3 & 4 & 4 & 0 & 0 \\
\hline \multicolumn{2}{|c|}{ Mean of difference (SD) } & \multicolumn{2}{|c|}{$0.03(0.14)$} & \multicolumn{2}{|c|}{$0.00(0.17)$} & \multicolumn{2}{|c|}{$0.02(0.10)$} & \multicolumn{2}{|c|}{$0.36(0.90)$} & \multicolumn{2}{|c|}{-} \\
\hline \multicolumn{2}{|l|}{$95 \% \mathrm{Cl}$} & \multicolumn{2}{|c|}{-0.08 to 0.03} & \multicolumn{2}{|c|}{-0.07 to 0.07} & \multicolumn{2}{|c|}{-0.07 to 0.02} & \multicolumn{2}{|c|}{-0.02 to 0.74} & \multicolumn{2}{|c|}{-} \\
\hline \multicolumn{2}{|c|}{ Observed agreement (\%) } & \multicolumn{2}{|c|}{-} & \multicolumn{2}{|c|}{-} & \multicolumn{2}{|c|}{-} & \multicolumn{2}{|c|}{-} & \multicolumn{2}{|c|}{88} \\
\hline \multicolumn{2}{|l|}{ Cohen's к } & \multicolumn{2}{|c|}{ - } & \multicolumn{2}{|c|}{ - } & & & & & & \\
\hline
\end{tabular}

$\mathrm{ES}=$ extraction socket; $\mathrm{S} 1$ = surgeon $1 ; \mathrm{S} 2$ = surgeon $2 ; \mathrm{A}=$ adequate; $\mathrm{C}=$ compromised; $\mathrm{D}=$ deficient; - = not applicable; $\mathrm{CI}=$ confidence interval. 
Table 4. (continued)

\section{Extraction Socket Hard Tissue Assessments by Surgeons 1 and 2}

\begin{tabular}{|c|c|c|c|c|c|c|c|c|c|c|c|}
\hline \multicolumn{2}{|c|}{$\begin{array}{l}\text { Presence of } \\
\text { Socket } \\
\text { Bone Lesions }\end{array}$} & \multicolumn{2}{|c|}{$\begin{array}{c}\text { Mesial Intradental } \\
\text { Bone Peak } \\
\text { Height (mm) }\end{array}$} & \multicolumn{2}{|c|}{$\begin{array}{l}\text { Distal Intradental } \\
\text { Bone Peak } \\
\text { Height (mm) }\end{array}$} & \multicolumn{2}{|c|}{$\begin{array}{c}\text { Mesio-Distal } \\
\text { Distance Between } \\
\text { Adjacent Teeth }(\mathrm{mm})\end{array}$} & \multicolumn{2}{|c|}{$\begin{array}{c}\text { ES Type According to } \\
\text { Hard Tissue Assessments } \\
\text { (I to III) }\end{array}$} & \multicolumn{2}{|c|}{$\begin{array}{c}\text { Total ES Type } \\
\text { (I to III) }\end{array}$} \\
\hline SI & S2 & SI & S2 & SI & S2 & SI & S2 & SI & S2 & SI & S2 \\
\hline No & No & 4 & 4 & 3 & 3 & 7 & 7 & 1 & 1 & I & 1 \\
\hline No & No & 2 & 2 & 3 & 3 & 8 & 8 & $\|$ & $\|$ & $\|$ & $\|$ \\
\hline No & No & 5 & 5 & 4 & 4 & 7 & 7 & 1 & 1 & I & 1 \\
\hline No & Yes & 2 & 2 & 3 & 3 & 6 & 6 & $\|$ & $\|$ & $\|$ & $\|$ \\
\hline No & No & 6 & 6 & 5 & 5 & 8 & 8 & 1 & 1 & $\|$ & $\|$ \\
\hline Yes & Yes & 4 & 4 & 4 & 4 & 8 & 8 & $\|$ & $\|$ & $\|$ & $\|$ \\
\hline Yes & No & 2 & 2 & 2 & 2 & 6 & 6 & $\|$ & III & III & III \\
\hline No & No & 5 & 5 & 4 & 4 & 8 & 8 & 1 & 1 & I & 1 \\
\hline No & No & 2 & 2 & 2 & 2 & 7 & 7 & $\|$ & $\|$ & III & III \\
\hline Yes & Yes & 4 & 4 & 3 & 3 & 7 & 7 & $\|$ & ॥ & III & III \\
\hline No & Yes & 3 & 3 & 2 & 2 & 7 & 7 & $\|$ & II & $\|$ & $\|$ \\
\hline Yes & Yes & 3 & 3 & 2 & 2 & 6 & 6 & III & III & III & III \\
\hline No & No & 4 & 4 & 4 & 4 & 6 & 6 & $\|$ & $\|$ & $\|$ & $\|$ \\
\hline No & No & 2 & 2 & 3 & 3 & 6 & 6 & ॥ & II & $\|$ & $\|$ \\
\hline No & Yes & 2 & 2 & 1 & 1 & 6 & 6 & $\|$ & $\|$ & $\|$ & $\|$ \\
\hline No & No & 2 & 2 & 2 & 2 & 7 & 7 & $\|$ & $\|$ & III & III \\
\hline No & No & 0 & 0 & 1 & 1 & 8 & 8 & $\|$ & III & III & III \\
\hline No & No & 4 & 4 & 4 & 4 & 6 & 6 & $\|$ & $\|$ & $\|$ & III \\
\hline No & No & 4 & 4 & 5 & 5 & 8 & 8 & 1 & 1 & 1 & 1 \\
\hline Yes & Yes & 2 & 2 & 3 & 3 & 7 & 7 & $\|$ & $\|$ & III & III \\
\hline Yes & Yes & 2 & 2 & 1 & 2 & 5 & 5 & III & III & III & III \\
\hline No & No & 3 & 3 & 2 & 2 & 6 & 6 & $\|$ & ॥ & $\|$ & $\|$ \\
\hline No & No & 5 & 5 & 4 & 4 & 6 & 6 & $\|$ & $\|$ & $\|$ & $\|$ \\
\hline No & No & 2 & 2 & 3 & 3 & 6 & 6 & $\|$ & $\|$ & ॥ & $\|$ \\
\hline No & No & 4 & 4 & 4 & 4 & 7 & 7 & 1 & 1 & 1 & 1 \\
\hline \multicolumn{2}{|c|}{-} & \multicolumn{2}{|c|}{-} & \multicolumn{2}{|c|}{-} & \multicolumn{2}{|c|}{-} & \multicolumn{2}{|c|}{-} & \multicolumn{2}{|c|}{-} \\
\hline \multicolumn{2}{|c|}{-} & \multicolumn{2}{|c|}{-} & \multicolumn{2}{|c|}{-} & \multicolumn{2}{|c|}{-} & \multicolumn{2}{|c|}{-} & \multicolumn{2}{|c|}{-} \\
\hline \multicolumn{2}{|c|}{84} & \multicolumn{2}{|c|}{100} & \multicolumn{2}{|c|}{96} & \multicolumn{2}{|c|}{100} & \multicolumn{2}{|c|}{92} & \multicolumn{2}{|c|}{96} \\
\hline \multicolumn{2}{|c|}{0.60} & \multicolumn{2}{|c|}{1.00} & \multicolumn{2}{|c|}{0.95} & \multicolumn{2}{|c|}{1.00} & & & & \\
\hline
\end{tabular}

$\mathrm{ES}=$ extraction socket; $\mathrm{S} 1$ = surgeon $1 ; \mathrm{S} 2$ = surgeon $2 ; \mathrm{A}=$ adequate; $\mathrm{C}=$ compromised; $\mathrm{D}=$ deficient; $-=$ not applicable; $\mathrm{CI}=$ confidence interval. 
plate width of 1 to $2 \mathrm{~mm}$ is needed. ${ }^{20,21} 11$ ) Presence of extraction socket bone lesions: this was identified visually using a dental mirror and sounding with the tip of a periodontal probe. Periodontal and traumatic bone lesions often jeopardize the success of immediate implant procedures. ${ }^{26,27} 12$ ) Intradental bone peak height: the distance from the tip of the intradental bone peak to the alveolar crest midline. Distances of 3 to $4, \geq 1$ to $<3$, and $<1 \mathrm{~mm}$ were defined as adequate, compromised, and deficient, respectively. A study ${ }^{39}$ demonstrated that the presence or absence of a bone crest influences the appearance of papillae between implants and adjacent teeth. 13) The mesio-distal (M-D) distance between adjacent teeth: distance measured in the M-D direction between two adjacent teeth's CEJ. An M-D distance $\geq 7 \mathrm{~mm}$ was deemed ideal for a regular $4 \mathrm{~mm}-$ diameter implant; a minimum of 1.25 to $1.5 \mathrm{~mm}$ of clearance is needed between the implant fixture and adjacent teeth for proper osseointegration and safety. ${ }^{40,41}$ In compromised cases, the M-D distance between adjacent teeth should be $>5$ and $<7 \mathrm{~mm}$. 14) Palatal angulation: angle between the extraction socket and neighboring teeth. Adequate extraction socket buccal angulation was characterized as $<5^{\circ} .41,42$ A compromised extraction socket buccal angulation was defined as $5^{\circ}$ to $30^{\circ} .43$ This was evaluated using a diagnostic wax-up and comparing to neighboring teeth.

All extraction socket assessment parameters were graded as adequate, compromised, or deficient by two oral surgeons (Table 2). All linear measurements were recorded to the closest $1 \mathrm{~mm}$ with the use of a periodontal probe. "

Type I classification means that all extraction socket parameters are in the adequate category. If at least one parameter was graded as compromised, the extraction socket was judged to be compromised or type II. If some parameter was graded as deficient, the extraction socket was judged to be deficient or type III (Table 2).

\section{Treatment Recommendation Based on the Proposed Classification}

If the extraction socket was graded as type I (adequate), immediate implant placement was performed. In type II sockets (compromised), immediate or delayed implantation with simultaneous soft or hard tissue augmentation was suggested. Staged implantation was indicated in type III (deficient) sockets. This should be done after soft and hard tissue augmentation or orthodontic treatment. In the case of a type III socket, alveolar process reconstruction was made with mucco-buccal flap elevation.

All implants were placed in the optimal threedimensional position: apico-coronally, 2 to $3 \mathrm{~mm}$ below the adjacent $\mathrm{CEJ} ;{ }^{13}$ bucco-lingually, 3 to $4 \mathrm{~mm}$ from the outside buccal flange; ${ }^{21}$ and mesio-distally, $\geq 1.5$ mm away from adjacent teeth. ${ }^{40,41}$ The remaining defects/dehiscences noted in type I or II sockets were corrected with deproteinized bovine bone. ${ }^{\# 4,45}$ Soft tissue deficiency was corrected using subepithelial connective tissue grafting.

One hour before surgery, the subjects were given $2 \mathrm{~g}$ V-penicillin; postoperatively, $2 \mathrm{~g}$ was given twice a day for 7 days. Chlorhexidine $0.2 \%$ oral rinses were prescribed twice daily for 2 weeks. The sutures were removed after 10 days. Provisional acrylic crowns were fixed to neighboring teeth.

\section{Esthetic Result Evaluation}

Evaluation of the esthetic result and soft tissue assessment were performed by surgeon 1 at the time of prosthesis placement. The evaluation was based on the following soft tissue parameters: soft tissue contour variations, soft tissue vertical deficiency, KG width, mesial and distal papillae appearance, and soft tissue quality. Soft tissue parameters and the esthetic result were evaluated as adequate, compromised, or deficient.

\section{Statistical Analysis}

Statistical analyses were performed using a statistical software program. * * Weighted Cohen's $\mathrm{k}$ was used to calculate interobserver reliability. When assessments were expressed as definite numeral data, the paired $t$ test was applied to analyze differences between measurements recorded by surgeons 1 and 2. Means \pm SDs were calculated. The Kolmagorov-Smirnov test was applied to test whether the distribution of parameters was normal. The marginal homogeneity test was used to detect if the treatment recommendation, which was made based upon socket classification, influenced esthetic soft tissue parameters.

\section{RESULTS}

In the assessment of the soft tissues of extraction sockets (Table 3 ), seven (25\%) cases were identified as adequate (type I) by both surgeons. Eleven (48\%) compromised extraction sockets (type II) were identified by surgeon 1 , and 10 (44\%) were identified by surgeon 2; deficient extraction sockets (type III) were identified in seven $(24 \%)$ and eight $(28 \%)$ cases, respectively. The biggest differences in interobserver agreement and weighted Cohen's $\kappa$ were found with regard to soft tissue contour ( $84.0 \%$ and 0.73 ), followed by soft tissue quality and gingival biotype evaluation $(88.0 \%$ and 0.80$)$. Despite the differences, the

\footnotetext{
II UNC-15 probe, Hu-Friedy, Chicago, IL.

\# Bio-Oss, Geistlich, Wolhusen, Switzerland.

* * SPSS/PC + statistical program, version 13.0 for Windows, SPSS Chicago, IL.
} 
Table 5.

Esthetic Soft Tissue Assessment Parameters Evaluated for Extraction Socket and at the Time of Prosthesis Placement by Surgeon 1

\begin{tabular}{|c|c|c|c|c|c|c|c|c|c|c|c|c|c|c|c|}
\hline \multirow[b]{2}{*}{ Subject \# } & \multirow[b]{2}{*}{ Tooth \# } & \multicolumn{2}{|c|}{$\begin{array}{c}\text { Soft Tissue } \\
\text { Contour } \\
\text { Variations (mm) }\end{array}$} & \multicolumn{2}{|c|}{$\begin{array}{c}\text { Soft Tissue } \\
\text { Vertical } \\
\text { Deficiency (mm) }\end{array}$} & \multicolumn{2}{|c|}{$\begin{array}{l}\text { KG Width } \\
\text { (mm) }\end{array}$} & \multicolumn{2}{|c|}{$\begin{array}{l}\text { Mesial Papillae } \\
\text { Appearance } \\
\text { (class) }\end{array}$} & \multicolumn{2}{|c|}{$\begin{array}{l}\text { Distal Papillae } \\
\text { Appearance } \\
\text { (class) }\end{array}$} & \multicolumn{2}{|c|}{$\begin{array}{l}\text { Soft } \\
\text { Tissue } \\
\text { Quality }\end{array}$} & \multirow{2}{*}{$\begin{array}{c}\text { ES Type } \\
\text { ES }\end{array}$} & \multirow{2}{*}{$\begin{array}{c}\text { Soft Tissue } \\
\text { Type } \\
\text { PP }\end{array}$} \\
\hline & & ES & PP & ES & PP & ES & PP & ES & PP & ES & PP & ES & PP & & \\
\hline I & 8 & 0 & 0 & 0 & 0 & 3 & 3 & I & I & I & 1 & $A$ & A & 1 & I \\
\hline 2 & 8 & 2 & 0 & 1 & -1 & 2 & 3 & $\|$ & 1 & 1 & I & C & A & $\|$ & I \\
\hline 3 & 9 & 0 & 0 & 0 & 0 & 5 & 5 & I & I & 1 & 1 & A & A & 1 & 1 \\
\hline 4 & 7 & 1 & 0 & 2 & 0 & 3 & 5 & $\|$ & 1 & 1 & 1 & C & A & $\|$ & I \\
\hline 5 & 8 & 0 & 0 & 0 & 0 & 3 & 3 & I & I & 1 & 1 & C & A & $\|$ & 1 \\
\hline 6 & 9 & 0 & 0 & 0 & 0 & 5 & 5 & । & I & । & 1 & A & A & 1 & । \\
\hline 7 & 6 & 3 & I & 2 & -1 & 3 & 4 & III & 1 & III & $\|$ & $\mathrm{D}$ & A & III & $\|$ \\
\hline 8 & 8 & 0 & 0 & 0 & 0 & 4 & 4 & I & I & I & I & $A$ & A & I & I \\
\hline 9 & 7 & I & 0 & 2 & 1 & 5 & 6 & $\|$ & 1 & $\|$ & I & C & A & III & $\|$ \\
\hline 10 & 10 & 0 & 0 & 0 & -1 & 2 & 3 & I & I & 1 & 1 & A & A & III & 1 \\
\hline 11 & 9 & I & I & 0 & 0 & 2 & 3 & $\|$ & I & I & I & C & A & $\|$ & $\|$ \\
\hline 12 & 10 & 3 & 0 & 1 & 0 & 3 & 5 & $\|$ & I & $\|$ & I & C & $A$ & III & 1 \\
\hline 13 & 7 & 0 & 0 & 0 & 0 & 2 & 2 & I & I & I & I & C & A & $\|$ & I \\
\hline 14 & 9 & I & 0 & 1 & -1 & 4 & 5 & $\|$ & I & 1 & I & C & A & $\|$ & I \\
\hline 15 & 11 & 0 & 0 & 0 & 0 & 2 & 3 & $\|$ & I & $\|$ & 1 & C & A & $\|$ & I \\
\hline 16 & 11 & 3 & I & 2 & 0 & 4 & 6 & $\|$ & $\|$ & $\|$ & I & $\mathrm{D}$ & C & III & $\|$ \\
\hline 17 & 9 & 2 & 0 & 2 & -1 & 5 & 5 & III & I & $\|$ & II & C & A & III & ॥ \\
\hline 18 & 6 & 0 & 0 & 0 & 0 & 3 & 3 & 1 & I & I & I & C & A & $\|$ & I \\
\hline 19 & 7 & 0 & 0 & 0 & 0 & 5 & 5 & I & I & 1 & I & $A$ & $A$ & 1 & 1 \\
\hline 20 & 8 & 2 & 0 & 1 & 0 & 4 & 5 & $\|$ & 1 & 1 & 1 & $\mathrm{D}$ & $A$ & III & I \\
\hline 21 & 6 & 0 & 0 & 0 & 0 & 3 & 3 & $\|$ & I & $\|$ & 1 & $C$ & $A$ & $\|$ & 1 \\
\hline 22 & 11 & I & 0 & 1 & 0 & 5 & 5 & $\|$ & 1 & $\|$ & I & $C$ & $A$ & $\|$ & I \\
\hline 23 & 10 & 0 & 0 & 0 & 0 & 4 & 4 & 1 & 1 & 1 & I & A & A & I & 1 \\
\hline 24 & 10 & 0 & 0 & 0 & 0 & 3 & 3 & $\|$ & I & 1 & I & $A$ & $A$ & $\|$ & 1 \\
\hline 25 & 7 & 0 & 0 & 0 & 0 & 5 & 5 & I & I & 1 & 1 & $A$ & $A$ & 1 & 1 \\
\hline$P$ value & & & & & & & & & & & & $<0$ & & & 0.001 \\
\hline
\end{tabular}

$\mathrm{ES}=$ extraction socket; $\mathrm{PP}=$ prosthesis placement; $\mathrm{A}=$ adequate $\mathrm{C}=$ compromised; $\mathrm{D}=$ deficient.

interobserver agreement was $96 \%$ and the weighted Cohen's $\kappa$ was 0.94 for soft tissue evaluation.

The hard tissue assessment (Table 4) revealed a trend similar to the soft tissue evaluation. Type I extraction sockets were identified in six cases by both surgeons (Table 4). Seventeen sockets were classified as type II by surgeon 1 , and 15 were identified by surgeon 2; two and four type III sockets were identified by surgeons 1 and 2 , respectively. The biggest differences in hard tissue assessment were found 
in extraction socket facial bone thickness; the Student $t$ test for paired samples was $0.02 \pm 0.10$ (Table 4). For hard tissue evaluation, the interobserver agreement was $92 \%$, and the weighted Cohen's $\kappa$ was 0.85 .

The overall interobserver agreement and weighted Cohen's $\kappa$ were $96 \%$ and 0.94 , respectively, for extraction socket classification. Only in one (4\%) case (subject 18) did the observers' opinions about the extraction socket type diverge (Table 4).

Five type I extraction sockets were treated using immediate implantation. In two cases, dehiscences $>2 \mathrm{~mm}$ were filled with bone grafts. For two type II sockets (subjects 14 and 24), immediate implantation was performed in conjunction with GBR and subepithelial connective tissue grafting. Nine type II sockets with compromised soft tissues or bone lesions were treated using delayed implantation with GBR and subepithelial connective tissue grafting. Nine type III sockets were judged to have deficient soft and hard tissues; hence, a staged approach was adopted. In these cases, soft and hard tissues were augmented first, and implants were placed after 5 to 6 months.

Table 5 shows the esthetic soft tissue assessment at the time of prosthesis placement by surgeon 1 . No deficient soft tissues were identified. Also, $80 \%$ of the sockets were graded as type I.

\section{DISCUSSION}

To obtain an optimal esthetic result when placing an implant directly into a fresh extraction site, it is essential to maintain the soft tissue surrounding the tooth. Caplanis et al. ${ }^{28}$ proposed a classification to address this issue; however, it fell short in distinguishing several assessments such as KG width, soft tissue contour variations, soft tissue quality parameters, implant palatal angulation, height of the alveolar process, and available bone beyond the apex of the extraction socket. Hence, it was our goal to propose a classification to overcome some of the deficiencies noted in the previously published classification systems, especially in the esthetic zone.

The classification we developed was based on soft tissue conditions (soft tissue quantity and quality and gingival tissue biotype) as well as on hard tissue parameters (height of alveolar process, available bone beyond the apex of the extraction socket, extraction socket labial plate vertical position, extraction socket facial bone thickness, presence of socket bone lesions, intradental bone peak height, $M$-D distance between adjacent teeth, and the need for palatal angulation) (Table 2). All of these items are critical in achieving optimum implant esthetics. ${ }^{22}$ Certain treatment approaches were recommended for each category of socket. For example, in the adequate category, an immediate implant placement is indicated, and a good esthetic outcome often can be anticipated.
Sites with compromised soft and hard tissue conditions can be corrected successfully using soft tissue grafting procedures and GBR. ${ }^{21,44-47}$ When there is a soft tissue deficiency, soft tissue graftings, such as subepithelial connective tissue grafting, should be attempted to augment tissue height and thickness so the esthetic results can be enhanced. ${ }^{46,48}$ It also is suggested that $\geq 2 \mathrm{~mm}$ dehiscence bony defects be corrected with GBR. ${ }^{44,45}$ With deficient soft and hard tissues, it always is preferable to wait until the socket is healed with adequate soft tissue support prior to implant placement. Patients also should be aware that the chance of achieving an esthetic outcome often is compromised if there is a deficient osseous architecture. ${ }^{9}$

The results of this study showed that the socket classification based upon soft and hard tissue evaluation is a valid and helpful tool to guide clinicians to achieve predictable esthetic outcomes, especially in the anterior maxillary region. This is supported by the $96 \%$ interobserver agreement and 0.94 weighted Cohen's $\kappa$ in the overall evaluation of the extraction sockets. It seems that it was most difficult to objectively evaluate the extraction socket facial bone thickness and other hard tissue parameters. Despite this, the strength of agreement was good (high weighted Cohen's $\mathrm{k}$ was found).

The evaluation of the esthetic result at the time of prosthesis insertion confirmed that the treatment approach recommended based upon this classification is reliable because $80 \%$ of cases following the suggested protocol achieved type I grade esthetic outcomes. Nonetheless, future studies that include a larger sample size with a longer follow-up period are needed to validate the initial results obtained in this study.

\section{CONCLUSION}

The classification proposed here based on extraction socket soft and hard tissues is an objective and helpful tool for socket assessment as well as for planning for future esthetic implant treatment.

\section{ACKNOWLEDGMENT}

The authors report no conflicts of interest related to this study.

\section{REFERENCES}

1. Schulte W, Kleineikenscheidt H, Linder K, Schareyka $\mathrm{R}$. The Tubingen immediate implant in clinical studies (in German). Dtsch Zahnarztl Z 1978;33:348-359.

2. Lazzara RJ. Immediate implant placement into extraction sites: Surgical and restorative advantages. Int $J$ Periodontics Restorative Dent 1989;9(5):332-343.

3. Knox R, Caudill R, Meffert R. Histologic evaluation of dental endosseous implants placed in surgically created extraction defects. Int $J$ Periodontics Restorative Dent 1991;11:364-375. 
4. Lundgren D, Rylander H, Andersson M, Johansson C, Albrektsson T. Healing-in of root analogue titanium implants placed into extraction sockets. An experimental study in the beagle dog. Clin Oral Implants Res 1992; 3:136-143.

5. Becker W, Becker BB. Promotion around e-PTFE Augmented implants placed in immediate extraction sockets. In: Buser D, Dahlin C, Schenk RK, eds. Guided Bone Regeneration in Implant Dentistry. Chicago: Quintessence Publishing; 1994:137-155.

6. Wilson TG, Schenk R, Buser D, Cochran D. Implants placed in immediate extraction sites: A report of histologic and histometric analysis of human biopsies. Int J Oral Maxillofac Implants 1998;13:333-341.

7. Nemcovsky CE, Artzi Z, Moses O, Gelernter I. Healing of marginal defects at implants placed in fresh extraction sockets or after 4-6 weeks of healing. A comparative study. Clin Oral Implants Res 2002;13:410-419.

8. Juodzbalys G. Instrument for extraction socket measurement in immediate implant installation. Clin Oral Implants Res 2003;14:144-149.

9. Bianchi AE, Sanfilippo F. Single-tooth replacement by immediate implant and connective tissue graft: A 1-9-year clinical evaluation. Clin Oral Implants Res 2004;15:269-277.

10. Avivi-Arber L, Zarb GA. Clinical effectiveness of implant-supported single-tooth replacement: The Toronto study. Int J Oral Maxillofac Implants 1996;11:311-321.

11. Scheller H, Urgell JP, Kultje C, Klineberg I, Goldberg PV, Stevenson-Moore P. A 5-year multicenter study on implant-supported single crown restorations. Int J Oral Maxillofac Implants 1998;13:212-218.

12. Haas R, Pollak Ch, Furhauser R, Mailath-Pokorny G, Dortbudak O, Watzek G. A long-term follow-up of 76 Brånemark single-tooth implants. Clin Oral Implants Res 2002;13:38-43.

13. Saadoun AP, Landsberg TC. Treatment classifications and sequencing for post extraction implant therapy: A review. Pract Periodontics Aesthet Dent 1997;9:933941.

14. Belser UC, Buser D, Hess D, Schmid B, Bernard JP, Lang NP. Esthetic implant restorations in partially edentulous patients - A critical appraisal. Periodontol 2000 1998; 17:132-150.

15. Araujo MG, Sukekava F, Wennstrom JL, Lindhe J. Ridge alterations following implant placement in fresh extraction sockets: An experimental study in the dog. $J$ Clin Periodontol 2005;32:645-652.

16. Araujo MG, Lindhe J. Dimensional ridge alterations following tooth extraction. An experimental study in the dog. J Clin Periodontol 2005;32:212-218.

17. Araujo MG, Wennstrom JL, Lindhe J. Modeling of the buccal and lingual bone walls of fresh extraction sites following implant installation. Clin Oral Implants Res 2006; 17:606-614.

18. Araujo MG, Sukekava F, Wennstrom JL, Lindhe J. Tissue modeling following implant placement in fresh extraction sockets. Clin Oral Implants Res 2006;17: 615-624.

19. Covani U, Cornelini R, Barone A. Bucco-lingual bone remodeling around implants placed into immediate extraction sockets: A case series. J Periodontol 2003; 74:268-273.

20. Spray JR, Black CG, Morris HF, Ochi S. Influence of bone thickness on facial marginal bone response: Stage 1 placement through stage 2 uncovering. Ann Periodontol 2000;5:119-128.
21. Kazor CE, Al-Shamari K, Sarment DP, Misch CE, Wang H-L. Implant plastic surgery: A review and rationale. J Oral Implantol 2004;30:240-254.

22. Garber DA. The esthetic dental implant: Letting restoration be the guide. J Oral Implantol 1996;22: 45-50.

23. Chang M, Wennstrom JL, Odman PA, Anderson B. Implant supported single-tooth replacements compared to contralateral natural teeth. Clin Oral Implants Res 1999;10:185-194.

24. Furhauser R, Florescu D, Benesch T, Haas R, Mailath G, Watzek G. Evaluation of soft tissue around singletooth implant crowns: The pink esthetic score. Clin Oral Implants Res 2005;16:639-644.

25. Rosenquist B, Grenthe B. Immediate placement of implants into extraction sockets: Implant survival. Int $J$ Oral Maxillofac Implants 1996;11:205-209.

26. Grunder U, Polizzi G, Goene R, et al. A 3-year prospective multicenter follow-up report on the immediate and delayed-immediate placement of implants. Int J Oral Maxillofac Implants 1999;14:210-216.

27. Novaes AB Jr., Marcaccini AM, Souza SL, Taba M Jr., Grisi MF. Immediate placement of implants into periodontally infected sites in dogs: A histomorphometric study of bone-implant contact. Int $J$ Oral Maxillofac Implants 2003;18:391-398.

28. Caplanis N, Lozada JL, Kan JYJ. Extraction defect assessment, classification, and management. J Calif Dent Assoc 2005;33:853-863.

29. Kirsch A, Ackermann KL. The IMZ osteointegrated implant system. Dent Clin North Am 1989;33:733791.

30. Buser D, Weber HP, Bragger U. The treatment of partially edentulous patients with ITI hollow-screw implants: Presurgical evaluation and surgical procedures. Int J Oral Maxillofac Implants 1990;5:165-175.

31. Zarb GA, Schmitt A. The longitudinal clinical effectiveness of osseointegrated dental implants: The Toronto study. J Prosthet Dent 1990;64:185-194.

32. Block MS, Kent JN. Factors associated with soft- and hard-tissue compromise of endosseous implants. $J$ Oral Maxillofac Surg 1990;48:1153-1160.

33. Sevor JJ. The use of free gingival grafts to improve the implant soft tissue interface: Rationale and technique. Pract Periodontics Aesthet Dent 1992;4:59-64.

34. Nordland WP, Tarnow DP. A classification system for loss of papillary height. J Periodontol 1998;69:11241126.

35. Claffey N, Shanley D. Relationship of gingival thickness and bleeding to loss of probing attachment in shallow sites following nonsurgical periodontal therapy. J Clin Periodontol 1986;13:654-657.

36. Davies SJ, Gray RJ, Young MP. Good occlusal practice in the provision of implant borne prostheses. $\mathrm{Br}$ Dent J 2002;192:79-88.

37. Rosenquist B, Ahmed $M$. The immediate replacement of teeth by dental implants using homologous bone membranes to seal the sockets: Clinical and radiographic findings. Clin Oral Implants Res 2000;11:572582.

38. Cardaropoli G, Lekholm U, Wennstrom JL. Tissue alterations at implant-supported single-tooth replacements: A 1-year prospective clinical study. Clin Oral Implants Res 2006;17:165-171.

39. Choquet V, Hermans M, Adriaenssens P, Daelemans P, Tarnow DP, Malevez C. Clinical and radiographic evaluation of the papilla level adjacent to single-tooth 
dental implants. A retrospective study in the maxillary anterior region. J Periodontol 2001;72:1364-1371.

40. Ohrnell LO, Hirsch JM, Ericsson I, Brånemark PI. Single-tooth rehabilitation using osseointegration. A modified surgical and prosthodontic approach. Quintessence Int 1988;19:871-876.

41. Adell R, Eriksson B, Lekholm U, Brånemark PI, Jemt T. Long-term follow-up study of osseointegrated implants in the jaws. Int J Oral Maxillofac Implants 1990;5:347-359.

42. Saadoun AP, Le Gall M, Touati B. Selection and ideal tridimensional implant position for soft tissue aesthetics. Pract Periodontics Aesthet Dent 1999;11:1063-1072.

43. Grunder U, Spielman HP, Gaberthuel T. Implantsupported single tooth replacement in the aesthetic region: A complex challenge. Pract Periodontics Aesthet Dent 1996;8:835-842.

44. Steenberghe D, Callens A, Geers L, Jacobs R. The clinical use of deproteinized bovine bone mineral on bone regeneration in conjunction with immediate implant installation. Clin Oral Implants Res 2000;11:210-216.
45. Hämmerle CHF, Lang NP. Single stage surgery combining transmucosal implant placement with guided bone regeneration and bioresorbable materials. Clin Oral Implants Res 2001;12:9-18.

46. Sclar AG. Strategies for management of single-tooth extraction sites in aesthetic implant therapy. $J$ Oral Maxillofac Surg 2004;62:90-105.

47. Juodzbalys G, Wang HL. Soft and hard tissue assessment of immediate implant placement: A case series. Clin Oral Implants Res 2007;18:237-243.

48. Langer $B$. The regeneration of soft tissue and bone around implants with and without membranes. Compend Contin Educ Dent 1996;17:268-270.

Correspondence: Dr. Gintaras Juodzbalys, Vainiku 12, LT46383 Kaunas, Lithuania. Fax: 370-37-323153; e-mail: gintaras@stilusoptimus.lt.

Submitted July 18, 2007; accepted for publication August 25, 2007. 